INTERNATIONAL JOURNAL OF RESEARCHES IN BIOSCIENCES, AGRICULTURE AND TECHNOLOGY (c) VISHWASHANTI MULTIPURPOSE SOCIETY (Global Peace Multipurpose So cie ty) R. No. MH-659/13(N) www.vmsindia.org

\title{
EFFECT OF MUTAGENS ON CHLOROPHYLL CONTENT OF MORPHOLOGICAL MUTANTS OF COWPEA [Vigna unguiculata (L.)Walp.]
}

\author{
B. S. Gaikwad ${ }^{1}$ and A.D. More ${ }^{2}$ \\ 1De partment of Botany, K.J.Somaiya College, Kopargaon, Dist: Ahmednage r (M.S.) \\ 2 Departme nt of Botany, Fergusson College, Pune-04. \\ bs.gaikwad69@gmail.com
}

\begin{abstract}
:
Cowpea (Vigna unguiculata [L.] Walp.) is one of the most important pulse crops in India. Cowpea variety- Phule Pandhari (PCP-9708) was used for present research work. The seeds we re treated with $0.050 \%, 0.075 \%, 0.10 \%$ and $0.125 \%$ concentration of EMS and gamma rays at doses of $20 \mathrm{kR}, 30 \mathrm{kR}, 40 \mathrm{kR}$ and $50 \mathrm{kR}$ and combination of $\mathrm{EMS}+$ gamma rays. Chemically, each chlorophyll molecule consists of porphyrin (tetrapyrol) and magnesium at the centre and a long chain hydrocarbon (phytyl) which is attached through a carboxylic acid group. Chlorophyll $a$ and $b$ occur in higher plants. In the present studies ten mutants like 1) Robust mutant 2) Branched mutant 3) Dark green mutant 4) Early flowering mutant 5) Late flowering mutant 6) Tall mutant 7) Dwarf mutant 8) Bold seeded mutant 9) Luxuriant mutant and 10) Divergently branched mutant of $\mathrm{M}_{4}$ generation induced through EMS, Gamma rays and Combination of both mutagens. Total chlorophyll content in morphological mutant of Cowpea was ranged from $1.16 \mathrm{mg} / \mathrm{gm}$ to $2.60 \mathrm{mg} / \mathrm{gm}$.
\end{abstract}

Keywords: Cow pea, EMS, Gamma rays, chlorophyll, mutants.

\section{Introduction}

Cowpea (Vigna unguiculata [L.] Walp.) is one of the most important pulse crops in India. Cowpea variety- Phule Pandhari (PCP-9708) was used for present research work. Cowpea (Vigna unguiculata [L .] Walp. ) belongs to family Fabaceae It is one of the most important pulse crops in India The re are about twenty two varieties of Cowpea have been recommended for different states and union territory. It is valued immensely as food and fodder for its role in biological nitrogen fixation. Induced mutagenesis may bring about changes in the overall morphology of plants and also increase in biochemical nature like carbohydrates, proteins, fats, vitamins and mine rals. Cowpea is an important grain legume throughout the tropics and subtropics, covering, Africa, Asia and Central and South America, as well as parts of southern Europe. Cowpea, a drought tolerant crop. It is cultivated as intercrop with maize, sorghum, millet.

The chlorophylls are the essential components for photosynthesis and occurred in chloroplast as green pigments in all green plants. They are made up of proteins and which are extracted in organic solvents such as ace tone. Chemically, each chlorophyll molecule consists of porphyrin (tetrapyrol) and magnesium at the centre and a long chain hydrocarbon (phytyl) which is attached through a carboxylic acid group. Chlorophyll $a$ and $b$ occur in higher plants. Witham et al., (1971) Chlorophyll was extracted in $80 \%$ acetone. The $663 \mathrm{~nm}$ and $645 \mathrm{~nm}$ wave length of spectrophotometer was used for different readings of chlorophyll a and chlorophyll $\mathrm{b}$, and by using the absorption coefficients; the amount of chlorophyll a and chlorophyll b was estimated.

\section{Material and Method}

Material: Experimental seed material of Cowpea (Vigna unguiculata [L.] Walp.) Variety - Phule Pandhari (PCP- 9708) was collected from Pulse and oil seed research station Pandharpur, Dist :- Solapur .released by Matma Phule Krishi Vidhyapeeth ,Rahuri ,Dist :- Ahmednagar. The experimental seed material of Cowpea (Vigna unguiculata [L]. Walp.) Variety- Phule Pandhari (PCP-9708) was collected from Pulse and oil seed research station, Pandharpur, DistSolapur. Released by Mahatma Phule Krishi Vidhyapeeth, Rahuri, Dist-Ahmednagar.

Mutagens used:- Physical mutagen Gamma rays, Chemical mutagen Ethyl methane sulphonate (EMS) were used for treatment.

Gamma rays treatment:-

The experimental seed material was irradiated at Nuclear Chemistry Division, Department of Chemistry, University of Pune Ganesh khind, Pune -411007.

For Gamma rays treatment the dry and healthy seed were packed and irradiated with $20 \mathrm{kR}, 30$ $\mathrm{kR}, 40 \mathrm{kR}$ and $50 \mathrm{kR}$ obtained from source Co60. EMS treatment: -

Chemical mutagen Ethyl methane sulphonate (EMS) was obtained from Spectrochem Pvt. Ltd. Mumbai with a molecular weight 124.16 and density 1.20 .Dry 
and healthy seeds were treated with EMS at the concentration of $0.050 \%, 0.075 \%, 0.10 \%$ and $0.125 \%$ for 6 hours.

The seeds of each treatment along with control were sown in research field by complete randomize block design (RBD) with three replication and result was recorded In M1 generation, for pollen sterility from each treatment at the time of flowering 25 randomly selected plants were used along with control .Pollen grains are stained with $2 \%$ acetocarmine stain. Stained pollen grains were considered as fertile pollen grains whereas pollen grains without staining we re considered as sterile pollen grains and values were recorded.

\section{Results}

In the present studies ten mutants like 1) Robust mutant 2) Branched mutant 3) Dark green mutant 4) Early flowering mutant 5) Late flowering mutant 6) Tall mutant 7) Dwarf mutant 8) Bold seeded mutant 9) Luxuriant mutant and 10) Diverge ntly branched mutant of $\mathrm{M}_{4}$ generation induced through EMS, Gamma rays and Combination of both mutagens. They were estimated for their chlorophyll content contents. The total chlorophyll content was estimated in different morphological viable mutants observed in the $\mathrm{M}_{4}$ generation of Cowpea [Vigna unguiculata (L.) Walp.].In the majority of viable mutants, the estimated values of the chlorophyll content was increased after mutagenic treatments.

The sample of control plant shows $1.29 \mathrm{mg} / \mathrm{gm}$ of total chlorophyll. The highest $2.60 \mathrm{mg}$. gm. amount of total chlorophyll content was observed in dark green leaves mutant the lowest $1.16 \mathrm{mg} / \mathrm{gm}$. amount of total chlorophyll content was found in divergently branched mutant. Total chlorophyll content in morphological mutant of Cowpea was ranged from $1.16 \mathrm{mg} / \mathrm{gm}$ to $2.60 \mathrm{mg} / \mathrm{gm}$. In chlorophyll'a' and chlorophyll 'b' was observed in the fluctuations. The fluctuation in chlorophyll pigments shows direct effect on physiology of plants.

\section{Discussion}

The chlorophyll a and chlorophyll b content was significantly increased as a result of mutage nic treatments. The similar result was reported by other researchers. Mejri et al., (2011) reported that chlorophyll a and chlorophyll b content was increased in the frequency of chlorophyll mutants depends on the dose/concentration of the mutagens. Chlorophyll a and b content was increased significantly after Gamma radiations.
Gamma radiation causes the mutation of leafle ts and chlorophyll deficiency in Faba beans was reported by (Mejri, et al., 2011). Similar result was reported by many researchers in viable mutants of different crop plants like Solanum by Kothekar, (1983), in Winged bean by Hakande, (1992), in Alfafa by More, (1992), in Pea by Satpute and Dhulgande, (2010), in Cluster bean by Shinde, (2013) and in French bean by Borkar, (2014).

From the above observations, there is a lot of scope for improving the Cowpea system through mutation breeding in regards to important features like chlorophyll content. The estimation of biochemical components indicated the application of mutation breeding in the development of superior genotypes carrying improved nutritional values in Cowpea.

Table No. 1 Effect of mutagens on chlorophyll content of morphological mutants of Cowpea [Vigna unguiculata (L.)Walp.]

\begin{tabular}{|l|c|c|c|}
\hline $\begin{array}{l}\text { Morphological } \\
\text { mutants }\end{array}$ & $\begin{array}{c}\text { Chlorophyll } \\
\text { 'a' } \\
\mathrm{mg} / \mathrm{gm}\end{array}$ & $\begin{array}{c}\text { Chlorophyll } \\
\text { 'b' } \\
\mathrm{mg} / \mathrm{gm}\end{array}$ & $\begin{array}{c}\text { Total } \\
\text { Chlorophyll } \\
\mathrm{mg} / \mathrm{gm}\end{array}$ \\
\hline Control & 0.60 & 1.09 & 1.29 \\
\hline $\begin{array}{l}\text { Robust } \\
\text { mutant }\end{array}$ & 0.96 & 1.75 & 2.19 \\
\hline $\begin{array}{l}\text { Branched } \\
\text { mutant }\end{array}$ & 0.70 & 1.27 & 1.46 \\
\hline $\begin{array}{l}\text { Dark green } \\
\text { mutant }\end{array}$ & 1.07 & 1.95 & 2.60 \\
\hline $\begin{array}{l}\text { Early flowering } \\
\text { mutant }\end{array}$ & 0.64 & 1.16 & 1.34 \\
\hline $\begin{array}{l}\text { Late flowering } \\
\text { mutant }\end{array}$ & 0.65 & 1.18 & 1.35 \\
\hline Tall mutant & 0.87 & 1.59 & 2.05 \\
\hline Dwarf mutant & 0.62 & 1.12 & 1.38 \\
\hline $\begin{array}{l}\text { Bold and large } \\
\text { seeded mutant }\end{array}$ & 0.67 & 1.21 & 1.48 \\
\hline $\begin{array}{l}\text { Luxuriant } \\
\text { mutants } \\
\text { mutant }\end{array}$ & 1.07 & 1.95 & 1.98 \\
\hline $\begin{array}{l}\text { Divergently } \\
\text { branched } \\
\text { mutant }\end{array}$ & 0.53 & 0.97 & 1.16 \\
\hline
\end{tabular}

\section{References:}

Arulbalachandran, D. and Mullainathan, L. (2009) Chlorophyll and Morphological mutants of Black Gram (Vigna mungo (L.) Hepper) derived by gamma rays and EMS. J Phytol. 1(4): 236241.

Arvindhan, S. and Das, L.D.V. (1996) Heterosis and combining ability in fodde $r$ cowpea for green fodder and seed yield. Madras Agricultural Journal 83:11-14.

Dhulgande, G. S., Ghogare, D. S., Dhale D. A. and Satpute, R. A. (2010) Mutagenic effect of gamma rays and EMS on frequency and Spectrum of Chlorophyll mutations in Pea 
(Pisum Sativum L.). Joumal of Ecobiotechnology. 2(8): 04-07.

Elangovan, M. and Selvraj, R. (1994) Effect of Gamma Irradiation on Biochemical Characteristics of Sunflower Seeds. J. Ind. Bot. Soc. 73: 345-346.

Gupta, SP, Lodhi GP. (1979.) Variability for fodder yield and its components in cowpea. Indian J. Agr. Sci. 46: 407-410.

Gustafsson, A. (1940) The mutation system of the chlorophyll apparatus. Lund Univ. Arasks. $N$. P. Adv. 36: 1-40.*
Jain, S.K. and Khandelwal, V. (2009) Mutagenic effect of EMS and DMS on frequency and spectrum of chlorophyll and other macro mutations in blackgram. Journal of Food Legumes. 22 (4): 264-268.

Raja Srinivas, T. and Vee rabadhiran, P. (2010) Efficiency and effectiveness of physical and chemical mutagens and their combination in inducing chlorophyll mutations in M2 generation of Lablab [Lablab purpureus (1.) Sweet var. Typicus.]. Electronic Journal of Plant Breeding. 1(4): 752-757. 